\title{
Az alapjogok nemzetbiztonsági szempontból történő korlátozása és az alapjogok korlátozásának alkotmánybírósági értelmezési gyakorlata II. ${ }^{2}$
}

The Restriction of Fundamental Rights for National Security and Its Interpretation by the Constitutional Court of Hungary 2

Az alapjogok korlátozásának kérdése egyidős maguknak az alapjogoknak az állam által történő elismerésével és védelmével. Azonban felmerült a kérdés, hogy az egyes alapjogoknak hol húzódik a határa, meddig érvényesülhetnek, illetve mikortól szükséges és kivánatos a korlátozásuk. Az alapjogok korlátozásának speciális esetét jelentik a nemzetbiztonsági érdekek. Az alapjogok korlátozásával kapcsolatos vitának új lendületet adott a Nyugat-Európát sújtó terrorizmus elleni védekezés, ezzel kapcsolatban előtérbe kerültek a nemzetbiztonsági érdekek és ezek alkotmányjogi vonatkozásai. Magyarországon az alapjogok tartalmának megállapításában és alakitásában az Alkotmánybíróság kiemelkedő szerepet töltött és tölt be. A jogértelmező tevékenységének kiemelt területe az alapjogok korlátozásának kérdése és gyakorlata. A tanulmány második része az alapjogok korlátozásának nemzetbiztonsági szempontok alapján történö alkotmánybírósági gyakorlatával, illetve a modern terrorizmussal megjelenő nemzetbiztonsági kihivásoknak a joggyakorlatra kifejtett hatásával foglalkozik.

Kulcsszavak: alapjogok, alapjogok korlátozása, Alkotmánybíróság, nemzetbiztonsági szempontok

Dr. Gesztei László doktorandusz, Pécsi Tudományegyetem, Állam és Jogtudományi Kar Doktori Iskola, ORCID: 0000-0002-7255-4112

2 Az Igazságügyi Minisztérium jogászképzés színvonalának emelését célzó programjai keretében 2018-ban valósult meg az alábbi tanulmány. 
The question of restricting fundamental rights is coeval with the recognition and protection of fundamental rights by the state. However, the question arises as to where the limitations of each fundamental right lie, how long they can take effect, and when their restriction is necessary and needed. National security interests are a special case of restricting fundamental rights. The debate on the restriction of fundamental rights has been given new impetus by the defence against terrorism in Western Europe, with this debate national security interests have come to the fore, as its constitutional aspects. In Hungary, the Constitutional Court has played primary role in establishing and shaping the content of fundamental rights. One of the priority areas of its interpretative activity is the question and practice of restricting fundamental rights. The second part of the study deals with the case law of the Constitutional Court on the restriction of fundamental rights on the basis of national security considerations and the impact of national security challenges of modern terrorism on legal practice.

Keywords: fundamental rights, restriction of fundamental rights, Constitutional Court of Hungary, interest of national security

\section{Az alapjogok korlátozása nemzetbiztonsági szempontok alapján}

Az állam akkor nyúlhat az alapjogok korlátozásának eszközéhez, ha másik alapvető jog vagy szabadság védelme más módon nem érhető el, azaz fennáll a szükségesség feltétele. Ezt követően vizsgálni kell, hogy a korlátozás arányban áll-e az érvényesíteni kívánt értékkel vagy célokkal. Ez röviden azt jelenti, hogy az elérendő, biztosítandó cél társadalmi súlya meghaladja vagy legalábbis eléri a korlátozással okozott jogsérelmet. A különféle célok társadalmi súlyát, a célok legitimitását meghatározó értékrend azonban hely, idő és szituáció függvénye, és nem utolsósorban a politikai térben uralkodó ideológiai áramlatok által meghatározott változó jelenség. Korábban sem volt vitatott, hogy az alapjogok korlátozása nemzetbiztonsági célok vagy a még tágabban értelmezett közbiztonság érdekében legitim célnak minősül, ezt a szemléletet a közelmúltban, különösen a Nyugat-Európában bekövetkezett terrorcselekmények tovább erősítették. Ez a folyamat értelmezhető a szélsőségesen individualista felfogás vereségeként, mivel az össztársadalmi érdekek érvényesítése szempontjából jelentős, korábban lényegében érinthetetlennek tekintett, személyhez tapadó alapjogok korlátozásáról lehet szó.

A társadalom védelme a bűncselekményektől vagy a fennálló társadalmi rend védelme mind kiemelkedően fontos cél, amelyeket csak a legelszántabb anarchisták vitatnak, azonban rendkívül bonyolult és kényes kérdés az alapjogok esetében annak meghatározása, hogy meddig arányos a korlátozás, és mikortól számít önkényesnek például a titkos információgyújtés, a megfigyelés vagy ezeknek az információknak a felhasználása. Az állami büntetőhatalom kizárólagossága és gyakorlásának a kötelezettsége a fennálló demokratikus társadalmi rendet kell hogy szolgálja. Ehhez azonban elkerülhetetlen az alapjogok korlátozása, bizonyos fokú sérülése, mivel 
a bűnüldözéshez és a bűncselekmények felderítéséhez hatékony eszközökre van szükség, a szükséges jogkorlátozás ezek érdekében éppúgy alkotmányosan indokolt, mint a búncselekmények elkövetőinek a büntetőpolitikai célok érvényesülése szerinti felelősségre vonására irányuló jogos társadalmi elvárás. Az Alkotmánybíróság a fenti összefüggéseket az alábbiak szerint fogalmazta meg: „Demokratikus jogállamban a büntető hatalom az állam - alkotmányosan korlátozott - közhatalmi jogosítványa a büncselekmény elkövetőinek felelősségre vonására. A büncselekmények a társadalom jogi rendjének sérelmét jelentik és a büntetés jogát az állam gyakorolja. A bűnüldözés kizárólagos joga egyben a büntető igény érvényesítéséről való gondoskodás kötelezettségét jelenti, a büntetőjogi felelősségre vonás egyben az állam alkotmányos kötelessége is. A büntetőhatalom gyakorlása szükségképpen érinti az egyének alkotmányos alapjogait. Az államnak az Alkotmányból levezethető kötelezettsége indokolja, hogy az állami büntetőhatalmat gyakorló szerveknek feladataik teljesítéséhez hatékony eszközeik legyenek, még ha ezek az eszközök, lényegüket tekintve, súlyosan jogkorlátozóak is."3

A nemzetbiztonsági érdekek vagy alkotmányos rend védelme önmagukban homályos meghatározások, amelyek lehetőséget biztosíthatnak a szükséges mértékü korlátozáson túlterjeszkedő intézkedések elfogadására és alkalmazására, ahogy azt az Amerikai Egyesült Államok terrorizmus elleni háborújának belpolitikai intézkedései során láttuk. Ezért fontos annak az elvnek a kimondása, hogy „,[...] alkotmányellenes a jog tartalmának korlátozása, ha az kényszerítő ok, nyomós közérdek nélkül történik, vagy ha a korlátozás súlya az elérni kívánt célhoz képest aránytalan". ${ }^{4}$ Az alapjogok korlátozásának esetében a szükségesség és az arányosság mellett, különösen a büntetőjogi tárgyú normák esetében kívánatos, hogy a törvényhozói akaratnak ne csak a célja derüljön világosan ki, hanem az alapjog korlátozására irányadó körülmények és feltételek is. Éppen ezért a jogalkotónak kifejezetten tartózkodnia kell az olyan normák elfogadásától, amelyek túlságosan rugalmas feltételeket határoznak meg, mert ez a jogi megoldás az önkényes jogalkalmazás lehetőségét rejti magában. Ez a veszély a legélesebben a nemzetbiztonsági érdekek védelmében alkalmazandó alapjogkorlátozó intézkedések és eszközök esetében jelenik meg. Az Amerikai Egyesült Államokból útjára indult, alkotmányosságra potenciálisan veszélyt jelentő jogalkotási tendencia lényege a nemzetbiztonsági érdekek érvényesülését hátráltató jogi akadályok lebontása és az egyes szolgálatok hatékonyságának növelése érdekében rugalmas felhatalmazáson alapuló jogi környezet kialakítása. Az Alkotmánybíróság 31/2015. (XI. 18.) AB határozat indokolásában a jogbiztonság elvének érvényesülésével kötötte össze a jogi normák világos és részletes megfogalmazásának kötelezettségét: „[62] Az Alkotmánybíróság szerint nemcsak a túlzottan általánosan (elvontan) megfogalmazott szabályok sértik a jogbiztonság elvét, de az is, ha a jogalkalmazói döntés jogszabályi kereteit a jogalkotó egyáltalán nem, vagy olyan túlzottan tágan határozza meg, hogy a jogalkalmazó szinte teljes egészében saját belátása szerint hozhat döntést. Ez ugyanúgy megnyitja az utat a szubjektív, önkényes jogalkalmazás előtt, mint mikor a jogalkotó a normavilágosságot sértő módon alkotja meg az alkalmazandó norma

13/2001 (V. 14.) AB határozat indokolásából, $A B H:$ 2001/177.

18/2000. (VI. 6.) AB határozat indokolásából, ABH 2000, 117., 123. 
szövegét." A nemzetbiztonsági érdekek és az alapjogok korlátozása meglehetősen ritkán került az Alkotmánybíróság látókörébe, mivel a hazai jogalkotási tendenciák és az alapjogok korlátozásának indokai közt a nemzetbiztonsági érdekek elvétve jelentek meg. Azonban az Alkotmánybíróság már néhány alkalommal kifejtette álláspontját, miszerint a nemzetbiztonsági érdekek önmagukban alkotmányos célt jelentenek, és ennek a védelmezése az állam kötelezettsége, a nemzetbiztonsági érdekek védelme során pedig az alapjogok korlátozásának eszköze alkalmazható megoldást jelent. „Az Alkotmánybíróság álláspontja szerint a nemzetbiztonsági érdekek védelme alkotmányos cél és állami kötelezettség. Az ország szuverenitása és az alkotmányos rendje a demokratikus jogállam múködéséhez nélkülözhetetlen alapértékek. Az ország szuverenitásának érvényre juttatása, politikai, gazdasági és honvédelmi érdekeinek megóvása, a szuverenitást, illetőleg az alkotmányos rendet sértő vagy veszélyeztető tevékenységek felderítése és elhárítása az államnak az Alkotmányból közvetlenül levezethető kötelezettsége [Alkotmány 2. § (2)-(3) bekezdés, 5. §, 35. § (1) bekezdés i) pont, 40/A. §, 48. §, 51. §]. A jogalkotás és az alkotmánybírósági vizsgálat szükségképpen elvont szintjén is elképzelhető, hogy [...] nemzetbiztonsági érdekek kerülnek veszélybe, és megvédésük érdekében az alkotmányos alapjogok korlátozására van szükség. [...]"5 Az Alkotmánybíróság 720/B/1997. AB határozat és a 3102/2018. (IV. 9.) $A B$ határozat indokolásával a fentieken túlmenve megfogalmazta, hogy bizonyos szabályozási tárgyak vagy élethelyzetek esetében a közbiztonság védelme érdekében az államnak alkotmányos kötelessége egyes alapjogok védelme, érvényesülése érdekében alapjogokat, például a tulajdonhoz való jogot korlátozza.

Az Alkotmány rendelkezett az alapjogok korlátozásának egyik speciális esetéről, amikor rendkívüli állapot, szükségállapot vagy megelőző védelmi helyzet miatt az alkotmányban meghatározott kivételektől eltekintve az alapjogok felfüggeszthetők, illetve korlátozhatók. Az Alkotmány különleges jogrendre vonatkozó szabályozási elvei változatlanul megtalálhatók az Alaptörvényben. Az Alaptörvény hatodik módosítása az aktuális kihívásokra reagálva kiegészítette a különleges jogrend eseteit a terrorveszélyhelyzettel. A zömével nyugat-európai terrorcselekmények elkövetését követően számos alkalommal láthattuk, hogy a társadalmat mélyen megrázó eseményeket követően bevezetik a rendkívüli állapotot.

A közelmúlt nyugati demokráciákat érő terrorcselekményeinek jellemzője, hogy az elkövetők stratégiáját az egyszerūség és a hatékonyság hatja át. A céljuk, hogy a terrorcselekmény minél brutálisabb legyen, és ha lehetséges, akkor szimbolikus üzenetet is hordozzon magában. Az elkövetett terrorcselekmény áldozatainak és sebesültjeinek magas száma a társadalom szubjektív biztonságérzetének szétrombolását is szolgálja. A terrorcselekményeket megelőző alacsony szintű tervezés különösen a magányos farkas jellegű elkövetők esetében jellemző, ilyenkor a cselekmény elkövetését általában minimális szervezés és tervezés előzi meg (tipikus formájuk a baltás, késes támadások), éppen ezért rendkívül nehéz a felderítésük és megakadályozásuk. A nemzetbiztonsági szolgálatok által alkalmazott széles körú információgyújtés

13/2001. (V. 14.) AB határozat indokolásából, ABH 2001, 177, 196., a korábbi indokolás érvényét az Alkotmánybíróság változatlan tartalommal megerősítette a 26/2013. (X. 4.) AB határozat [143] indokolásában. 
és megfigyelés következtében a jelentősebb szervezést és összehangolt tevékenységet igénylő terrorcselekmények esetében magas a lebukás kockázata.

A nemzetbiztonsági szolgálatok tevékenységével elsődlegesen akkor találkozik az átlagember a médiában, amikor egy terrorcselekmény kapcsán a szolgálatok hiányosságai vagy hibái kerülnek a kommunikáció előterébe. A szolgálatok tevékenységének sajátosságából fakadóan a sikeres és hatékony munkavégzés eredményei, például egy terrorcselekmény megelőzése, terroristasejt felszámolása vagy a terrorizmus finanszírozását szolgáló anyagi javak lefoglalása már jóval kevesebb hírértékkel rendelkezik, sőt, a szolgálatok tevékenységének, módszereinek és eszközeinek nagy része a sikeres akciókat követően is rejtve kell, hogy maradjon. A szolgálatok munkája akkor sikeres, ha a potenciális elkövetőket még a tervezés, felkészülés stádiumában sikerül lefülelni és ártalmatlanítani. Egy konkrét terrorcselekmény megakadályozása elkövetés közben, még mielőtt személyi sérüléssel, halállal vagy jelentősebb javak megsemmisülésével járna, már részben szerencse kérdése. Egy terrorcselekmény elkövetése, még akkor is, ha bizonyos esetekre képtelenség felkészülni vagy azokat megelőzni, a szolgálatok információgyűjtő, megfigyelő és adatkiértékelő tevékenységének hiányosságát mutatja. Ilyenkor a politikai vezetők részéről a különleges jogrend bevezetése elkerülhetetlen lépés, mivel a fokozott rendőri és katonai jelenlét és ellenőrzés csökkenti egy újabb terrorcselekmény elkövetésének lehetőségét, növeli a szubjektív biztonságérzetet, továbbá azt a képet tükrözi, hogy az államhatalom kézben tartja a helyzetet. A politikai ellenzék mindig felveti a kormányzat felelősségét és cselekvési inkompetenciáját, elfelejtve azt, hogy az alkotmányos keretek jelentősen korlátozzák az állam lehetőségeit a terrorcselekmények felderítéséhez, megelőzéshez szükséges, az alapjogokat érintő intézkedések alkalmazása terén. A terrorizmus elleni minél teljesebb védelem iránti igény és a terrorizmussal mint elkerülhetetlen civilizációs jelenséggel való együttélés szükségessége komoly politikai vitákat generált. Tudomásul kell venni, hogy a terrorizmus bizonyos jelenségei ellen például a magányos farkas típusú elkövetők vagy a látható előzmények nélkül radikalizálódó, a bevándorlók másod-, harmadgenerációja köréből kikerülő elkövetők elleni védekezés szinte lehetetlen.

A sikeres felderítőtevékenységet nehezíti, hogy Európában az egyes tagországok közti szabad közlekedés jogát megszerző személyek könnyedén el tudnak túnni a szolgálatok látóköréből, ezért nem véletlen, hogy a terrorizmus elleni küzdelem európai szintű kihívása a szolgálatok munkájának összehangolása és az információáramlás megteremtése. Ettől azonban az államnak a fennálló társadalmi rend védelmére és polgárai életének, biztonságának megóvására vonatkozó köztelezettségét el kell látnia a rendőrségen, a katonaságon és a nemzetbiztonsági szolgálatokon keresztül. Ebben a munkában a személyi létszám okozta korlátokkal és a technológiai korlátokkal is tisztában kell lenni, de ami ennél fontosabb, hogy az alkotmányok és a jog védelmezik nemcsak az áldozatok és sértettek alapjogait, hanem az elkövetők és a potenciális gyanúsítottak alapjogait is.

A terrorizmus elleni küzdelemnek számos országban az egyik legfontosabb belpolitikai következménye, hogy a nemzetbiztonsági érdekeknek fokozatosan alárendelődnek az alapjogok. Korábban is voltak az alapjogokat korlátozó intézkedések és jogalkotási próbálkozások, de a politikai és társadalmi ellenállás ezeket nagyrészt 
kordában tartotta. Fontos hangsúlyozni, hogy az alapjogok korlátozásának amerikai rendszere nem koherens elképzelések alapján alakult ki, hanem fokozatosan, ad hoc jelleggel. A politikai akadályok nagy része Barack Obama adminisztrációja alatt hárult el, a demokrata politikusok és értelmiségi holdudvaruk ettől kezdve lényegesen kevesebb kritikát fogalmazott meg az alapjogokat korlátozó intézkedésekkel szemben. ${ }^{6}$ Belpolitikai téren a terrorizmus elleni küzdelemben a terrorcselekmények megelőzésére és felderítésére fordították figyelmüket a jogalkotók, a nemzetbiztonsági szolgálatok által igényelt pénzügyi, technikai és személyzeti igényeket a terrorfenyegetettség miatt biztosították számukra. Ez kiterjedt a jogszabályi háttér átalakítására is, a nemzetbiztonsági szolgálatok a munkájukat nehezítő, akadályozó tényezőként tekintenek gyakran az alapjogokra, ezért a terrorizmus elleni küzdelem céljának alárendelve rugalmasabb jogszabályi háttérre volt szükség.

A technikai lehetőségek által biztosított szinte korlátlan és tömeges megfigyelés alanyai nemcsak az állampolgárok és adataik lettek, hanem a jogi személyek is, ezek főleg a terrorizmus támogatása miatt kerültek a látótérbe. A jogi személyek esetében a terrorizmus támogatásának, terrorcselekmények elkövetéséhez eszközök biztosításának feltárása jelenti a titkos információgyűjtés elsődleges célját, a jogi személyek pénzeszközeinek befagyasztása körül alakult ki a legjelentősebb vita. Nemzetbiztonsági szempontból a gyanú felmerülésének esetében indokolt a pénzeszközök mielőbbi zár alá vétele, mert ennek hiányában a pénzeszközöket eltüntethetik, és máshol felhasználhatják, ha sokáig várnak az intézkedések foganatosításával a gyanú megerősítéséig, úgy nő az esélye, hogy az eszközök kikerülnek a látótérből, vagy legrosszabb esetben felhasználják arra a célra (terrorcselekmény elkövetése), amire szánták. Pusztán nyomozati célok tekintetében fontos kérdést jelent, hogy meddig érdemes várakozni arra, hogy a megfigyelés eredményeképpen sikerül-e leleplezni egy nagyobb terroristahálózatot, szervezett bűnözői csoportot, vagy egy tényleges bűncselekmény elkövetésének megelőzése érdekében a rendelkezésre álló információk alapján a nyomozó hatóságoknak, nemzetbiztonsági szerveknek a látókörébe került személyeket le kell-e tartóztatniuk. Az eszközök és a pénzforrások útjának feltérképezése komoly segítséget jelenthet egyfelől a tényleges elkövetőkhöz való eljutásban és a konkrét terrorcselekmények megakadályozásában, másfelől a támogatói, segítői kör megismerésében és elszámoltatásában. Ennek a kiterjedt hírszerző tevékenységnek az eredményeként akár állami szereplőhöz is el lehet jutni. Ennek eredménye a terrorizmust támogató államok nyilvántartása. A terrorizmus elleni harc eszközei fokozatosan elfogadottá és megszokottá váltak, függetlenül attól, hogy az alapjogokat milyen súlyosan korlátozták, erre szembetűnő példát jelentenek a pénzmosás elleni rendelkezések. „Bár mostanra evidenciának tűnik, amikor a hetvenes években megjelentek az első ilyen jellegű szabályok, sokan megütköztek az alapvetően az ügyfélbizalomra építő magánszemély nyakába vart ilyen jellegű bűnüldözési, sőt preventív igazságszolgáltatási feladatok felbukkanásán. A közösségi bűnmegelőzés elvének ilyen kiterjesztése végül is elfogadottá vált, így manapság már nincs abban

Magyarországon az Alkotmánybíróság például a 3038/2014. (III. 13.) AB határozatában kimondta, hogy az egyes alapjogok, mint például a személyes adat, az önrendelkezési jog és az emberi méltóság alkotmányos védelmével szembeni korlátozás az egyes bűncselekmények, terrorcselekmények elhárítása, az elkövetés veszélyének minimalizálása érdekében össztársadalmi érdekként megengedhető. 
semmi meglepő, hogy a pénzintézetek nemcsak büntetőeljárások során a büntetőhatóságok kérésére, de gyanús tevékenység észlelésekor (jogszabályi előírásokat követve) »maguktól« szolgáltatnak információt az ügyfélről."7

Az Iszlám Állam a korábbi, fennhatósága alatt álló területeket gyakorlatilag elvesztette, ám a térségből kiinduló migrációs hullámban való elvegyülés ideális lehetőséget biztosít a korábbi harcosoknak a felelősségre vonás előli menekülésre és az Európába történő beszivárgásra. Abba az Európába, ami az elmúlt időben politikailag rendkívül megosztottá vált, és különféle kihívásokra nem tudott egységes és hatékony válaszokat adni. Európa nyugati felén megjelenő kihívások egybeesnek a közelmúltban végbement politikai változásokkal. Ezek jelentős mértékben kapcsolódnak a demográfiai viszonyokhoz és az egyes államokban megfigyelhető etnikai alapú változásokhoz, a migrációhoz, valamint az elszaporodó terrorcselekményekhez. Az Európai Unió politikai, gazdasági ügyei és egyes államok pénzügyi problémái elterelték a figyelmet a bevándorlás árnyoldalairól, azonban a gyakran alacsony szintǔ integráció, a jóléti állam pénzügyi lehetőségeinek és teherbíró képességének korlátai rávilágítanak az egyes társadalmak eltartóképességének és toleranciájának határaira. A többségi társadalom egyre inkább elutasító a bevándorló/migráns hátterű személyekkel szemben. Ezt a közhangulatot új, radikálisan gondolkodó, a bevándorlást és az Európai Unió központosító törekvéseit ellenző politikai mozgalmak és pártok karolják fel, emellett megfigyelhető a korábban mérsékelt pártok kommunikációjának radikalizálódása is. Egyre szembetűnőbb a bevándorló hátterü személyek körében az integráció hiánya és a többségi társadalom normáinak és értékeinek elutasítása, ami a nagyvárosok no-go zónái körüli vitákban jelent meg a legélesebben. Ezeknek a kvázi szegregátumoknak a puszta létét egyes politikusok tagadják, mások pedig igyekeznek a valóságnál kedvezőtlenebb képet festeni róluk. A migránsbűnözés kifejezés elterjedése és a mögötte található cselekmények új kihívás elé állították a bűnüldöző szerveket és a nemzetbiztonsági szolgálatokat. A többségi társadalom ellenérzését fokozzák a bevándorlókkal szemben a média által bemutatott erőszakos hírek a terrorcselekményekről és az emelkedő bűnözési statisztikákról, illetve az egyes hírszolgáltatók által egyoldalúan bemutatott, úgynevezett „migránssimogató” hírek. A többségi társadalom növekvő türelmetlensége miatt a bevándorlók és menedékkérők a már meglévő erőteljes kulturális különbségeket felerősítve egyre kevésbé kívánnak integrálódni az őket jogilag ugyan befogadó, de egyre inkább kirekesztő szemléletű társadalmakba, és egyre inkább saját kultúrkörük szokásait kívánják követni, ami gyakran a befogadó társadalom értékeinek lenézésével, megvetésével párosul. Ennek a folyamatnak a végén teljesen megszűnik az átjárás a migrációs hátterű személyek és a többségi társadalom között. Az európai jólét és gazdagság reménye újabb és újabb tömegeket fog vonzani az afrikai és közel-keleti térségből, ahol a túlnépesedés, a klímaváltozás és a fegyveres konfliktusok miatt a menekültekből, gazdasági bevándorlókból folyamatos lesz az utánpótlás. Az újonnan érkezők a gyakran bizonytalan személyazonosságuk miatt önmagukban biztonsági kockázatot hordozhatnak, de az igazi problémák középtávon jelennek meg. Az iszlám hitú bevándorlók egy részének eredménytelen integrációja és ezeknek a tömegeknek

PAP 2007, 49 
a kirekesztettségérzése, ami gazdasági sikertelenséggel is párosul, ideális táptalajt jelent a radikális hitszónokoknak, politikai erőknek és terroristaszervezeteknek.

A 20. században a terrorizmus eszközéhez tipikusan különféle ideológiák győzelemre segítése érdekében, illetve szeparatista törekvések érvényre juttatása miatt nyúltak, a vallási alapú terrorizmus csak mérsékelten jelent meg, elsősorban izraeli és palesztin érdekkonfliktus keretében. A terrorizmus új, globális szerveződési formáinak megjelenése és a korábbitól eltérő elkövetési magatartások nagyrészt felkészületlenül érték a nemzetbiztonsági szolgálatokat. Ma a médiát az iszlám nevében elkövetett terrorcselekmények uralják. A terroristák motivációját is meghatározza a hírérték, mivel sokkal „nagyobbat szól” egy londoni, berlini vagy párizsi terrorcselekmény - még akkor is, ha kevés az áldozatok száma -, mint egy távoli konfliktuszóna poros piacán elkövetett terrorcselekmény. A modern terrorizmussal olyan láthatatlan ellenség jelent meg, aminek hatására életbe lépő állami és társadalmi védelmi mechanizmusok az állandó készenléttel és gyanakvással fokozatosan erodálják a társadalom szövetét és a korábban vitán felül álló és érvényesülő alapjogokat. A radikális iszlám és a terrorizmus elleni küzdelem során az európai jogrendszer lényegében megoldhatatlan választással szembesül, mivel az emberi jogok érvényesülése és a nemzetbiztonsági érdekek érvényesülése közt az egyensúlyi helyzetet nagyon nehéz megtalálni, és egy win-win szituáció gyakorlatilag elképzelhetetlen. A diszkrimináció tilalma és a vallásszabadság elvei az iszlamista terrorizmus elleni felderítőtevékenység során látványosan kerülnek előtérbe, mivel a vallási meggyőződés, az etnikai hovatartozás vagy a származási ország következtében kerülhetnek egyesek a nemzetbiztonsági szolgálatok vizsgálódási körébe. ${ }^{8}$ Jogvédő szervezetek gyakran kifogásolják a hatóságok terrorizmus elleni küzdelme során megjelenő diszkriminatív gyakorlatot. „A diszkrimináció tilalmának elve azonban csak abban az esetben tiltja, hogy két helyzetre eltérő bánásmódot alkalmazzanak, ha a két helyzet megegyezik, és semmilyen alkotmányos cél nem igazolja az eltérő bánásmódot. Könnyű belátni azonban, hogy a leküzdendő veszélyeket nem a katolikus vagy zsidó fundamentalisták jelentik, márpedig csak és kizárólag ebben az esetben lehetne igazolni az azonos bánásmódot." 9

A fentiek alapján joggal merül fel a kérdés, hogy alkotmányosan meddig elfogadható és igazolható bizonyos eszközök alkalmazása, illetve az állam alapjogokat korlátozó fellépésének hol vannak a határai, még akkor is, ha egy olyan fontos cél érdekében is történik, mint a terrorizmus elleni védekezés vagy a társadalmi rend megóvása. A történelem során az információ megszerzésének legkézenfekvőbb eszközét az érintett személy testi, lelki kínzása jelentette, az elkövető beismerő vallomását a bizonyítékok királynőjének is hívták. A kínzás alkalmazása esetén nemcsak a sötét középkorra kell gondolni, a 20. század is bővelkedett olyan eseményekben, amikor az emberi jogok elértéktelenedtek: világháborús időszakok, a második világháborút követő hidegháborús éra fegyveres konfliktusai, de ide tartoznak a számos eltérő

\footnotetext{
8 A bűnüldözés eszköztárában az Amerikai Egyesült Államokban rendkívül elterjedt a racial profiling eljárás, amit szintén számos alkalommal minősítettek diszkriminatívnak vagy megbélyegzőnek. Magyarországon hasonló kifogások merültek fel a rendőrség igazoltatási gyakorlatával szemben, mivel jogvédők problémásnak tartják, hogy az igazoltatások esetében magas a cigány származású, kinézetű személyek érintettsége. MATHIEU 2017, 67.
} 
ideológiát szolgáló diktatórikus rendszerek is. A kínzás és az embertelen, megalázó bánásmód tilalmát számos egyezmény tartalmazza, ennek az érvényesülése jogállami minimumnak számít, mégis láthatjuk, hogy a politikai vagy nemzetbiztonsági érdek ezt könnyedén felülírja. ${ }^{10} \mathrm{~A}$ probléma alapját az jelenti, hogy a nemzetbiztonsági érdek előtérbe kerülésével a tágan értelmezett nemzetbiztonságot veszélyeztető bármilyen cselekményre (terrorcselekmény előkészítése és elkövetése, kémkedés, felforgató tevékenység vagy akár az álhírek „fake news” elleni fellépés, mint ahogy az Amerikai Egyesült Államokban az elnökválasztást követően politikai és médiaeseményekből láthattuk) vonatkozó információ megszerzése és felhasználása szentesíti a megszerzésükhöz alkalmazott eszközöket. Különösen zavarók voltak a Trump elnöknek a témában elhangzott nyilatkozatai és általa a Központi Hírszerző Ügynökség (CIA) igazgatójának jelölt Gina Haspelnek a szenátusi meghallgatásán elhangzott, a Haspel által vezetett titkos CIA-börtönben (black site prison) a terroristagyanús személyek kínzásának gyakorlatával kapcsolatos tájékoztatása, illetve a jelölt alkalmasságát dicsérő nyilatkozatok. Ez a fajta hozzáállás azért különösen aggasztó, mert nem egy banánköztársaságról vagy egy távoli diktatúráról beszélünk, hanem a demokrácia, a szabadság és az emberi jogok bajnokának tartott Amerikai Egyesült Államokról. „[...] a pekingi olimpia évében a belföldi és nemzetközi terrorizmus fenyegetéseire hivatkozó kínai biztonsági intézkedések mellett az az Egyesült Államok lép fel a kínai demokrácia hiányosságainak kritikájával, amely a terrorizmus elleni küzdelem jelszavával beavatkozik a szuverén államok belügyeibe, a nemzetközi biztonsági intézkedések drákói szigorításának programját vallja, és saját államterületén is maradéktalanul igyekszik érvényesíteni azt."11

A kínzásnak és az embertelen bánásmódnak az egész tárházát felvonultatta a terrorizmus elleni háború során elkövetett atrocitások sora, ezeket a cselekményeket nemcsak az afgán, iraki kormányerők vagy az Iszlám Állam harcosai követték el, hanem a koalíciós erők tagjai is. Az egyes államok által elkövetett jogsértések felderítése rendkívül nehézkes, főleg háborús övezetben, ennek oka, hogy a jogsértő cselekményeket tipikusan az adott állam megbízásából, annak parancsára követik el az állam tágan felfogott érdekei, céljai érdekében. Az elkövetői kör szintén az adott állam képviseletében jár el: katonák, kormánytisztviselők, nemzetbiztonsági szolgálatok alkalmazottjai vagy egyszerú zsoldosok (Private Military Company-k - PMC-k alkalmazottjai), ezért a jogsértések feltárása és az elkövetők felelősségre vonása érthető módon az érintett államnak nem érdeke. Az Amerikai Egyesült Államok magatartása korábban inspiráló és pozitív irányadó mintának számított, mára azonban a multipolárissá váló világban egyre inkább negatív példát mutat a nemzetközi jog csak számára hasznos rendelkezéseinek figyelembevételével és a vélt amerikai érdekek elsőbbségének szélsőséges érvényesítésével. A kialakult világrend egyensúlyára, szövetségesek érdekeire fittyet hányó nemzeti önzés politikája a többi szuverén állami szereplő számára is ragadós példa. Komoly veszélyeket rejt magában az, ha az egyes

10

Bizonyos államokban, mint például Észak-Korea vagy a Közel-Kelet fegyveres konfliktusok, polgárháborúk által feldúlt, vagy az Iszlám Állam uralma alatt tartott területeken az emberi jogok érvényesüléséről és tiszteletéről nem beszélhetünk. Az emberi jogok nem létezhetnek ott, ahol a kínzás, a rabszolgaság és a gyilkolás gyakorlatilag a mindennapok szerves része.

11 ÁDÁM 2005, 37. 
államok a nemzetközi jog szabályai közül csak a számukra hasznosakat, az igazukat alátámasztó rendelkezéseket alkalmazzák, az ezzel szemben álló szabályokat pedig látványosan negligálják.

A kínzást nemzetközi egyezmények, az egyes államok alkotmányai az elérendő céltól függetlenül kifejezetten tiltják, a terrorizmus által jelentett kihívások a jogi tiltást ugyan nem kezdték ki, de a társadalmi gondolkodás számos országban, különösen az Amerikai Egyesült Államokban bizonyos esetekben már egyáltalán nem kezeli elítélendően az információgyűjtésnek, a vallomás megszerzésének ezt a módját. A jogi irodalmat is régóta foglalkoztatja ez a kérdéskör, a legjobban a „ketyegő bomba” eseteként hivatkoznak erre a dilemmára. A dilemma lényege röviden: az elfogott terrorista tudja, hogy melyik metróállomáson található a beélesített bomba, de ezt nem hajlandó elárulni, ebben az esetben morálisan és jogilag indokolható-e a terrorista megkínzása az információért cserébe. ${ }^{12}$ A dilemmának az alábbi aspektusai jelennek meg: a kínzásnak, mint információszerzésnek a hatékonysága, a kínzás erkölcsi-morális igazolhatósága, valamint a kínzás jogi megengedhetőségének kérdése, különösen az emberi jogok vonatkozásában. Mivel a kínzás tilalma abszolút jogot jelent, ezért a kérdés jogi megítélése teljesen egyértelmű. A 2002. évi Daschner-ügy tárgyalásán a bíróság az elrabolt gyermek fogvatartási helyének kínzás, kényszervallatás alkalmazásával történő kicsikarása kapcsán az alábbiakat fogalmazta meg: „[...] az állam még életvédelmi kötelezettségének teljesítése körében sem lépheti túl az állami cselekvés alkotmányos korlátait. A kínvallatás gyakorlatát nem tưrheti meg a jogállam, még a legszélsőségesebb határhelyzetekben sem. A biztonság csalóka illúziójáért nem áldozhatjuk fel a civilizáció fundamentális vívmányait." ${ }^{13}$ A kínzással történő információgyűjtés morálfilozófiai és politikai megítélése már egyáltalán nem olyan egyértelmű, mint a jogi megítélése. Az Amerikai Egyesült Államok által a terroristákon előszeretettel alkalmazott vízbe fojtást szimuláló (waterboarding) vagy alvásmegvonással járó (sleep deprivation) kínzási módszerek elterjedése ismét felélénkítette a vitát arról, hogy az ártatlanok (amerikaiak) védelme érdekében a kínzás igazolható és alkalmazható módszer-e. Komoly veszélyt jelent, hogy amint társadalmilag elfogadott, hogy jogilag igazolható a kínzás egy jelentősebb, szélesebb körü jogsérelem megelőzése érdekében vagy az ártatlanok védelme érdekében, akkor előbb vagy utóbb a „kisebbik rossz” (még akkor is, ha azt modern nyelvezettel nemzetbiztonsági érdeknek nevezzük) választása következtében végletekig relativizálhatjuk bárkinek az emberi jogait.

12 Michael Levin sokat vitatott, The Case for Torture című cikke szélsőséges példák alapján (Manhattan-szigeten elhelyezett atombomba vagy a terroristák által a kórházból elrabolt újszülött szituációja) veti fel, hogy a kínzás szélsőséges esetekben jogszerűnek tekinthető ártatlan életek megmentése céljából. Előrevetíti, hogy a nyugati demokráciáknak szembe kell néznie azzal, hogy terroristák tízezrek életét fenyegethetik majd és megmentésükre egyedül a kínzás biztosít megoldást. Egy kritika az említett cikkről: Critical review on "The case for torture” Elérhető: http://userpage.fu-berlin.de/ shommeri/critical-review-on-the-casefor-torture/ (A letöltés dátuma: 2019. 02. 10.)

13 Tenni vagy nem tenni? - őszintén a kényszervallatásról (2016). Elérhető: https://arsboni.hu/oszinten-akenyszervallatasrol/ (A letöltés dátuma: 2018. 10. 26.) 


\section{Összegzés}

Az alapjogok esetében hangsúlyozni szükséges absztrakt etikai, filozófiai jellegüket, illetve tartalmuknak az egyes alkotmányokban megjelenő eltérő meghatározottsági szintjét. Az alapjogoknak az alkotmányokban megjelenő szabályozásával felmerült a kérdés, ami az egyes alapjogok konkrét tartalmának és érvényesülésük feltételeinek meghatározására irányult. Az egyes alapjogokra vonatkozó részletes jogi szabályozás kimunkálása elődlegesen a jogalkotó, alkotmányozó feladata, az alapjogoknak azonban nincs egységes, pontos és általánosan elfogadott meghatározása. Az alapjogok tényleges tartalmának kialakításában az egyes országok alkotmánybíróságai is jelentős szerepet játszottak, a rendszerváltást követően a magyar Alkotmánybíróságra ez hatványozottan érvényes volt. Elvitathatatlan az Alkotmánybíróság hozzájárulása a hazai jogfejlődéshez és az alapjogok tartalmának, korlátainak, valamint érvényesülési feltételeinek kialakításához. Az Alkotmánybíróság aktivizmusát és tevékenységét a politika és a társadalom részéről általánosságban elismerés övezte, ugyanakkor a túlzott aktivizmus és a láthatatlan Alkotmány fikciójának előtérbe kerülése miatt számos kritika is érte. Az Alkotmánybíróság alapjogokat érintő értelmező tevékenysége kimagasló jelentőségú, mivel az alapjogok a mindennapokban elkerülhetetlenül konfliktusba kerülhetnek egymással és más alkotmányos értékekkel, célokkal. Az Alaptörvény I. cikk (3) bekezdésében szereplő meghatározás értelmében: „alapvető jog más alapvető jog érvényesülése vagy valamely alkotmányos érték védelme érdekében, a feltétlenül szükséges mértékben, az elérni kívánt céllal arányosan, az alapvető jog lényeges tartalmának tiszteletben tartásával korlátozható." Ezeknek a kollízióknak a feloldása elsődlegesen a jogalkotó feladata, de a jogalkotói tevékenységet a napi politikai érdekek gyakran negatív irányba befolyásolják. Ezért a napi politikától távol álló Alkotmánybíróság eltérő szemszögből vizsgálja az egymással ütköző jogok és értékek egymás javára történő korlátozását.

Az állam akkor élhet az alapjogok korlátozásának eszközével, ha másik alapvető jog vagy szabadság védelme más módon nem érhető el, vizsgálnia kell, hogy a korlátozás arányban áll-e az érvényesíteni kívánt értékkel vagy célokkal. A problémát az okozza, hogy a különféle célok társadalmi súlyát, a célok legitimitását meghatározó értékrend hely, idő és szituáció függvénye, illetve nem elhanyagolható mértékben politikai ideológia kérdése. Az alapjogok korlátozásának problematikája alapvetően a szükségesség és arányosság megítélése körül forog. Az alapjogok korlátozásának egyik legkevésbé vitatott esete a közbiztonság érdekében történő korlátozásuk, hiszen a globalizált világ számos veszélyt rejt magában. A nemzetbiztonsági kockázatok leglátványosabb megnyilvánulási formáját az új típusú terrorizmus jelenti. Az egyes államok a lakosság szubjektív biztonságérzetének növelése és a nemzetbiztonsági szolgálatok feladatellátásának elősegítése érdekében jelentős jogszabályi változtatásokat fogadtak el, ezek jellemzője, hogy a nemzetbiztonsági érdekeknek fokozatosan alárendelődnek az alapjogok. Az alkotmányos értékeket is kikezdő jogalkotási tendencia a nemzetbiztonsági szolgálatok munkáját nehezítő, akadályozó tényezőként tekintett az alapjogokat a terrorizmus elleni küzdelem céljának alárendelve rugalmasabb jogszabályi hátteret alakít ki. A nemzetbiztonsági érdekek érvényesítése az egyének jogainak új típusú, tömegeket érintő korlátozását jelenti. Amíg ez a tevékenység 
a terrorizmus támogatásának felszámolásához, terrorcselekmények elkövetésének megakadályozásához vezet, addig a titkos információgyűjtést, megfigyelést vagy akár az alapjogok ennél súlyosabb korlátozását is elfogadja a lakosság. Azonban nagyon vékony és nehezen felismerhető az a határ, amit átlépve az alapjogok korlátozása meghaladja a szükséges és arányos mértéket, és pusztán öncéllá válik.

\section{Felhasznált irodalom}

ÁDÁM Antal (2005): A biztonság, mint jogi érték. In Balogh Ágnes - Hornyák Szabolcs szerk.: Tanulmánykötet Erdősy Emil professzor 80. születésnapja tiszteletére. Pécs. MATHIEU, Bertrand (2018): A jog a demokrácia ellen? Budapest, Századvég Kiadó.

PAP András László (2007): Rendvédelem, terrorizmus, emberi jogok. Székesfehérvár, Kodolányi János Főiskola.

\section{Jogi források}

13/2001. (V. 14.) AB határozat

18/2000. (VI. 6.) AB határozat

26/2013. (X. 4.) AB határozat a szerencsejáték szervezéséről szóló 1991. évi XXXIV. törvény egyes rendelkezései alaptörvény-ellenességének megállapítására és megsemmisítésére irányuló indítvány és alkotmányjogi panaszok elutasításáról 3038/2014. (III. 13.) AB határozat az alkotmányjogi panasz elutasításáról

\section{Internetes forrás}

Critical review on "The case for torture” (2018) Elérhető: http://userpage.fu-berlin. de/ shommeri/critical-review-on-the-case-for-torture/ (A letöltés dátuma: 2019. 02. 10.)

Tenni vagy nem tenni? - őszintén a kényszervallatásról (2016). Elérhető: https://arsboni.hu/oszinten-a-kenyszervallatasrol/ (A letöltés dátuma: 2019. 02. 10.) 